\title{
ПОЕТИЧНА ПСИХОТЕРАПІЯ ЯК ЗАСІБ ФАСИЛІТАЦІЇ ДУХОВНОЇ ТРАНСФОРМАЦІЇ ОСОБИСТОСТІ
}

\author{
Зіновія Карпенко \\ доктор психологічних наук, професор, заслужений діяч науки і техніки України, \\ професор кафедри психології розвитку \\ Прикарпатський національний університет імені Василя Стефаника \\ 76025, Україна, м. Івано-Франківськ, вул. Шевченка, 57 \\ zinoviia.karpenko@pnu.edu.ua, http://orcid.org/0000-0002-0747-2591
}

\section{Інеса Гуляс}

доктор психологічних наук, доцент, доцент кафедри психології

Чернівецький національний університет імені Юрія Федьковича

58012, Україна, м. Чернівці, вул. Коцюбинського, 2

i.gulyas@chnu.edu.ua, http://orcid.org/0000-0002-4960-4011

\begin{abstract}
Анотація
Статтю присвячено аксіопсихологічному обгрунтуванню застосування короткочасної поетичної психотерапії 3 використанням творів морально-етичного й екзистенційнодуховного спрямування. Мета дослідження: описово-феноменологічне й експериментальностатистичне доведення ефективності терапії поезією в короткочасній перспективі. Завдання дослідження полягали в обгрунтуванні доцільності використання поезії в якості засобу гармонізації поточних психічних станів і фасилітації пролонгованих процесів духовної трансформації особистості; презентуванні аксіопсихологічного (суб’єктно-ціннісного) формату організації та змістового наповнення поезіотерапії; експериментальній i статистичній верифікації ефективності застосованого формату поетичної терапії. Методи дослідження: шкала ситуативної тривожності Ч. Спілбергера і Ю. Ханіна, методика діагностики психічних станів Г. Айзенка, опитувальник якості життя Р. Еліота; описовостатистичні методи, кореляційний аналіз. Формувальний експеримент проводився у формі поетичного вечора-тренінгу. Експериментальну вибірку склали 18 дорослих представників середнього класу.

В результаті дослідження було обгрунтовано, що в процесі поезіотерапії відбувається гармонізація поточних психічних станів і фасилітація духовної трансформації особистості згідно 3 аксіопсихологічним форматом відбору i презентації авторських текстів, що визначається принципом інтегральної суб'єктності, за яким функціонально-динамічні зрушення у смислових переживаннях реципієнтів поезії простежуються на організмічному, психосоматичному (відносний суб'єкт); індивідуальному, адаптаційно-діяльнісному (моносуб'єкт); інтеракційному, морально-комунікативному (полісуб'єкт); автентичному культуротворчому (метасуб'єкт); універсальному, трансцендентному (абсолютний суб'єкт) рівнях. Доведено, що духовно-трансформаційний потенціал поезії визначається інтенсивністю і гостротою втілених у ній моральних дилем і в ближній часовій перспективі виявляється в динаміці психоемоційних станів, поданих на різних рівнях суб'єктності реципієнта поезії.
\end{abstract}


Висновки. Встановлено загальну тенденцію до зростання внутрішньої інтегрованості (гармонізації) психічних станів, що є предиктором зрілої життєвої позиції, сили Я, здатності до самостійного, автентичного смислопокладання особистості. Водночас відбувається позитивна переоцінка реципієнтами поезії якості свого життя, що супроводжується більшим самоприйняттям і асертивністю.

Ключові слова: аксіологічна психологія, бібліотерапія, духовна трансформація особистості, поетична психотерапія, фасилітація розвитку особистості.

\section{Вступ}

Бурхливі трансформаційні процеси, що відбуваються в сучасному світі, помножені на загрози і виклики ковідної пандемії, актуалізують пошуки форм психологічної допомоги людині, котра потерпає від емоційно-комунікативної деривації та фрустрації на шляху досягнення особистих життєвих цілей. 3'являється запит на несправедливо недооцінені, а почасти і маловідомі, психотерапевтичні засоби консультативної психології та соціальнопсихологічного тренінгу (зокрема тренінгу особистісного зростання), до яких, 3-поміж іншого, належить бібліотерапія (буквально - книголікування) і такий іiі сегмент, як поетична психотерапія (інакше - поезіотерапія чи терапія поезією).

Попри те, що благотворний вплив читання психічний стан людини помітили ще в Античності, бібліотерапія і поетична терапія завдячують своїй номінації Семюелю Крозерсу, який у 1916 році вперше вжив термін «бібліотерапія», а в 1932 році Якоб Морено вперше використав термін «психопоезія». За визначенням, прийнятим у 1920-ті роки Асоціацією лікарняних бібліотек США, бібліотерапія - це «використання спеціально для читання матеріалу як терапевтичного засобу в загальній медицині та психіатрії з метою розв'язання особистих проблем за допомогою скерованого читання» (Карпова \& Лейтес, 2014: 178).

3 часом склалося три основні напрями розвитку цього методу: «медичний», де основний вплив здійснює терапевт, а роль бібліотекаря допоміжна; «бібліотечний», де керівництвом «лікувальним читанням» займається спеціально підготовлений працівник бібліотеки; «комплексний», представники якого вважають, що бібліотерапія $є$ допоміжною, а в низці випадків і рівноправною частиною лікувального процесу при неврозах і соматичних захворюваннях. Однак сучасна царина поетичної терапії окреслилася завдяки зусиллям американського психіатра Джека Ліді (1921-2004), який відкрив клініку поетичної терапії в Брукліні, а в 1986 році видав класичну працю «Поезія як цілитель: виправлення неспокійного розуму». Відтак було створено першу Асоціацію з поетичної терапії (АРТ) у Нью-Йорку (Allen, Carter \& Pearson, 2019).

Найвидатнішим сучасним представником поетичної терапії (ПТ) по праву вважається Ніколас Мазза, який у 2016 році опублікував 2-ге видання фундаментальної праці «Поезіотерапія: теорія і практика», зміст якої охоплює історію появи, розвитку та теоретикоприкладні аспекти ПТ; застосування ПТ в різних організаційних форматах - 3 окремими людьми, сім'ями, групами і громадами; методичні особливості ПТ з представниками різних вікових груп - дітей та молодших підлітків, юнаків, різновікових дорослих і людей похилого віку; огляд досліджень ефективності ПТ, способів здобуття поезіотерапевтичної освіти, можливостей професійного розвитку та нових напрямів ПТ (Mazza, 2016).

В довіднику з бібліо/поетичної терапії, вперше виданому в 1986 році, визначено бібліотерапію як використання літератури в усіх іiі формах для зміцнення психічного здоров'я (Hynes \& Hynes-Berry, 2011). В свою чергу, поезіотерапія трактується, як 
терапевтичний процес, в якому поезія використовується з метою особистісного зростання та емоційного зцілення (Leedy \& Reiter, 2016).

До становлення бібліотерапії на європейських теренах долучився енциклопедично освічений книговидавець - виходець із Росії Микола Рубакін (1862-1946). Як стверджує дослідниця його наукового доробку Н. Демчук, «Бібліологічна психологія М. Рубакіна наукове вивчення психічних процесів, пов'язаних зі створенням, циркуляцією та утилізацією друкованої, рукописної та усної мови» (Демчук, 2008: 167). Саме М. Рубакін увів у науковий вжиток термін «бібліологічна психологія», а в 20-ті роки XX століття створив у Лозанні (Швейцарія) Міжнародний інститут бібліопсихології. Він закликав до системного вивчення тріади «читач - книга (текст) - автор», причому підкреслював, що головний складник цієї триєдності - читач. ВПлив автора (сіяча) на читача (грунт) змістом і формою літературного твору вчений образно називав «посівом бібліопсихологічних цінностей», які мають соціокультурну детермінацію. Завдання бібліопсихології М. Рубакін убачав у тому, щоб перетворювати слово зі знаряддя непорозуміння на знаряддя взаємного розуміння; знаходити наукові способи формулювання власних думок мовою не лише своєї, а й чужої психології, переходити від розуміння слів до розуміння реальності, яку вони позначають; перетворювати слово на зброю боротьби за істину і справедливість, з чого випливає і завдання боротися 3 тренуванням і муштрою, зі всіляким «bourrages des cranes» (облудною пропагандою) (Рубакин, 1977: 41). Надзвичайну актуальність ця теза М. Рубакіна набула в епоху засилля фейків і кібербулінгу.

В контексті презентованого у цій статті дослідження, під бібліо (поезіо) терапією будемо вважати лікувальний (розвивально-корекційний i реконструктивнотрансформаційний) вплив на людину (пацієнта, клієнта, пересічного реципієнта) художньої, документально-історичної, науково-популярної літератури (поетичних творів) 3 метою оптимізації іiі психоментального функціонування, а також зміцнення фізичного здоров'я i підвищення якості життя загалом.

Метою дослідження було описово-феноменологічне й експериментально-статистичне доведення ефективності терапії поезією в короткочасній перспективі. Завдання дослідження: 1) обгрунтувати доцільність використання поезії в якості засобу гармонізації поточних психічних станів і фасилітації пролонгованих процесів духовної трансформації особистості; 2) презентувати аксіопсихологічний (суб'єктно-ціннісний) формат організації та змістового наповнення короткочасної групової поезіотерапії; 3) експериментально i статистично верифікувати ефективність застосованого формату поетичної терапії.

\section{Методи дослідження}

Теоретичні - індукція та дедукція, аналіз і синтез, порівняння, класифікація, абстрагування, конкретизація, систематизація, узагальнення, теоретичне моделювання; емпіричні - особистісні опитувальники з метою психодіагностики психічних станів: шкала ситуативної (реактивної) тривожності Ч. Спілбергера і Ю. Ханіна (повний варіант), методика діагностики психічних станів Г. Айзенка, опитувальник якості життя Р. Еліота; формувальний експеримент (проведення поетичного вечора-тренінгу); статистичні знаходження середніх арифметичних та стандартних відхилень емпіричних показників, кореляційний аналіз за Пірсоном. 


\section{Результати та дискусії}

В емпіричних дослідженнях, присвячених вивченню ефективності арт-терапії (терапії творчим самовираженням, експресивної, креативної, наративної психотерапій), в рамках яких використовується поезія як допоміжний психотерапевтичний засіб, зазвичай, застосовуються описово-герменевтичні (якісні) методи. При цьому емпіричні дані отримують шляхом збору i систематизації самозвітів 3 наступним контент-аналізом, феноменологічним чи дискурсивним аналізом тощо. Що стосується методів математичної статистики, то вони в дослідженням такого штибу застосовуються вкрай рідко, позаяк визнається, що ті володіють низькою дискримінантною валідністю, яка не дає змоги визначити зрушення в тонких душевних переживаннях унаслідок їх зазвичай неусвідомленої, латентної та синкретичної внутрішньоособистісної динаміки. До поодиноких випадків, в яких математико-статистичні методи все ж використовуються, належить вивчення ефективності бібліотерапії в контексті терапії прийняттям і прихильністю студентів японських коледжів, які навчаються за кордоном. Це експериментальне дослідження показало достовірне зміцнення психічного здоров'я і психологічної гнучкості досліджуваних кількістю 70-ти осіб (Muto, Hayes \& Jeffcoat, 2011). Дослідження, проведене в Ірані, свідчить про те, що групова поетична терапія може поліпшити настрій та надію у жінок з раком молочної залози (Daboui, Janbabai \& Siavash, 2018), а дослідження, виконане на Мальті, присвячено впливу поезії на розвиток емпатії в молоді (Xerri \& Agius, 2015).

Попри це експериментальних досліджень ефективності «чистої» ПТ явно бракує, незважаючи на те, що ПТ застосовували до осіб з тривожними розладами, депресією та шизофренією, в психологічній підтримці людей похилого віку та невиліковно хворих та ін. Основною вадою цих досліджень вважають опертя на самозвіти клієнтів чи пацієнтів медико-реабілітаційних закладів, оскільки ті, на думку більшості науковців, не слугують достатньо надійною основою для достовірних висновків.

Ліквідувати зазначену ваду допоможе звернення до змішаних методів емпіричного дослідження - поєднання якісних (описових, герменевтичних) і кількісних (математикостатистичних) методів збору і обробки емпіричних даних, що сумарно дозволить отримати повноту інформації рефлексивно-феноменологічного спектру з одночасною фіксацією величини і значущості семантичних зрушень у структурі аксіосфери учасників ПТ. Така методологічна тріангуляція покликана довести (чи спростувати) генеральну гіпотезу: духовно-трансформаційний потенціал поезії визначається інтенсивністю і гостротою втілених у ній за допомогою художніх засобів моральних дилем та екзистенційно-духовних прагнень і в ближній часовій перспективі виявляється в динаміці психоемоційних станів, презентованих на різних рівнях особистості (реципієнта поезіі) як інтегрального суб'єкта життєздійснення.

В публікації 3.С. Карпенко, присвяченій презентації поетичної збірки авторки під назвою «Дорогою причастя», стверджується: «Безперервні пошуки ефективних психотерапевтичних засобів, що ведуться 3 урахуванням пост-постнекласичного типу раціональності, потребують новітньої психопрактичної тріангуляції, а саме: доповнення до погляду на особистість як чинника «інтертекстуальних» взаємодій та продукту «щасливого» збігу випадкових соціокультурних контекстів у точці біфуркації - вимушеного ціннісного самовизначення особи, яке, втім, завжди ситуативне, а відтак - аксіологічно знівельоване, бо потенційно поліваріантне, множинне і релятивне, - доповнення цього погляду вистражданим 
поверненням до ідеї суб'єкта як цілісного (тотального) автора своїх духовно-душевнотілесних трансформацій в універсумі людської культури» (Карпенко, 2010: 177).

Згідно з артикульованим авторкою принципом інтегральної суб'єктності, людина, як інтенціональна істота, прагне до розкриття свого потенціалу на таких рівнях буття:

1) відносного суб’єкта (біологічного індивіда, психосоматичного організму), наділеного здатністю рефлекторного налаштування («передчуваю») на сприятливі умови життя й орієнтованого на ключову цінність «вітальність» (здоров’я);

2) моносуб'єкта (власне суб'єкта умовно індивідуальної діяльності), який здійснює діяльність певного предметного змісту (пізнання, спілкування, праця), згідно з виробленими соціальними нормами і технічними стандартами. Адаптивна, нормовідповідна активність моносуб'єкта забезпечується сформованою здатністю «треба» - морально-психологічною саморегуляцією за допомогою усвідомленого обов'язку;

3) полісуб'єкта чи особистості як суб'єкта суспільно розподіленої діяльності, керованої імперативом моральної свідомості - сумлінням або інстанцією «мушу» i спрямованої на цінність творення добра для ближніх;

4) метасуб’єкта як індивідуальності, що репрезентує себе в актах творчої діяльності й унікальних внесках у культуру. Суб'єктна здатність цього рівня втілюється цілепокладанням «буду» або «смію» i забезпечує досягнення індивідуального інноваційного ефекту, оцінюваного за естетичними канонами прекрасного;

5) абсолютного суб'єкта - людини як носія універсальної духовності з притаманною їй супердиспозицією «благо» як результату розуміння смислу існування конкретного сущого у світовому порядку (суб'єктна здатність «приймаю»).

Принцип інтегральної суб'єктності було покладено в основу підбору психодіагностичних засобів фіксації короткочасних емоційно-ціннісних змін, які відбулися в результаті участі досліджуваних в організованому студентом магістратури зі спеціальності «Психологія» Русланом Павловим поетичному вечорі-тренінгу.

Відтак, у контексті зазначеного методологічного принципу було відібрано такі діагностичні методики, шкальні показники яких логічно i змістовно узгоджуються 3 уявленням про цілісну особистість як інтегрального суб'єкта життєздійснення:

1) шкали ситуативної тривожності Ч. Спілбергера і Ю. Ханіна й особистісної тривожності Г. Айзенка діагностують функціональні емоційні (психосоматичні відчуття) зрушення на рівні відносного (умовного) суб'єкта життєдіяльності;

2) шкала ригідності Г. Айзенка діагностує ступінь готовності моносуб'єкта прийняти чи не прийняти інспірований поезією формат феноменологічного вчування в образносмисловий контекст запропонованих для слухання текстів;

3) шкала агресивності Г. Айзенка діагностує в особистості як полісуб'єктові здатність емоційно відгукнутися на поміщені у відібрані тексти інтенції морального змісту, що спонукають до перегляду якості повсякденних комунікацій учасників тренінгу;

4) шкала фрустрації Г. Айзенка діагностує спроможність метасуб'єкта, як творчої індивідуальності, протистояти екзистенціальним викликам і скористатися особистісними ресурсами й соціокультурними шансами з метою власного життєконструювання;

5) діагностика якості життя Р. Еліота дозволяє охопити весь обшир екзистенціалів людського буття (рівень універсальності або абсолютного суб'єкта життєздійснення).

Першочерговим завданням експерименту була актуалізація полісуб'єктного і метасуб'єктного рівнів життєздійснення особистості за допомогою спеціально підібраних 
віршів, що презентують складні моральні колізії (через що часто відносяться до розряду «дидактичних»), а також віршів, що репрезентують смисложиттєві пошуки, одвічні духовні прагнення і митарства людини. 3 огляду на разовість та невелику тривалість поетичного вечора-тренінгу сподіватися на стійку духовну трансформацію особистості було б нереалістично, але припускалося, що принаймні на рівні психічних станів - переживань тривоги/спокою, ригідності/пластичності, агресивності/толерантності, фрустрованості/віри в себе, оптимізму, відчуття суб'єктивного благополуччя (якість життя) - певні позитивні зрушення вдасться зафіксувати.

До участі в заході було залучено 18 дорослих представників середнього класу віком від 18 до 37 років - найманих працівників і дрібних підприємців. Експозиція заходу містила добірку з 16-ти творів різних поетів, яких об’єднувала аксіпсихологічна тематика. Добірка віршів була сформована і поділена на три основні блоки:

\section{1-й блок «Стосунки Чоловік-Жінка»}

«Как много дней, что выброшенны зря» Э. Рязанова, декламація В. Глазунова; «Жди меня и я вернусь/ Чуєш ти чекай мене» (російсько-українська версія) К. Симонова, декламували: О. Герасим’юк, А. Сеїтаблаєв, С. Нищук, А. Мазур; «28 лет» Юлії Вихарьової, декламація - А. Егоян; «Как много тех, с кем можно лечь в постель...» Е. Асадова, декламація - Л. Юдін; «Он хлопнул дверью...» Н. Задорожньої, декламація - В. Глазунов; «Скажи, а ты меня сегодня любишь?» Н. Задорожньої, декламація - В. Глазунов; «На что мы тратим жизнь...» А. Загодіної, декламація - Д. Вітрук.

\section{2-й блок «Стосунки Батьки-діти»}

«Они обнявшись утром пили чай» Н. Задорожньої, декламація - В. Глазунов; «Она случайно уронила ложку» Валентини Кисельової, декламація - В. Глазунов; «Девочке три...» М. Матросової, декламація М. Матвейчук.

\section{3-й блок «Ставлення до себе та життя загалом»}

«Однажды все проходить безвозвратно» І. Самаріної, декламація - В.Глазунов; «Ты веришь в Бога? - Я его не видел...» І. Самаріної, декламація - В. Федорів; «Сегодня Бог проснулся утром рано» I. Самаріної, читає В. Федорів; «Якщо ти нарікаєш на життя» Р. Дудича, декламація - О. Мотрич; «Когда мне встречаться в людях дурное» Е. Асадова, декламація Д. Вітрука; «Научитесь с собой дружить...» Е. Асадова, декламація М. Калужських.

Завершував вечір рефлексивний зворотний зв'язок, під час якого слухачі повідомляли, що, незважаючи на унікальність способу i форми «інобуття» поетичних творів у їх художньо-естетичному досвіді, катарсичний ефект і смислотворчий імпульс терапії поезією вражає. Це підтверджують і результати статистичної обробки експериментальних даних, зібраних до і після ПТ, виконаної І. Гуляс.

3 метою коректного порівняння емпіричних показників актуальних психічних станів до і після поетичного вечора-тренінгу було проведено їхнє переведення у стени (див. табл. 1). Помітно, що в обох випадках середні психодіагностичні результати ледь більші медіани - числа 5. При цьому стандартне відхилення досить значне (в межах 2,3 - 2,6), що засвідчує значний розкид даних i необхідність окремого монографічного описового дослідження кожного учасника заходу.

Наочне подання даних на рис. 1 демонструє такі тенденції: 1) зниження після тренінгу показників особистісної тривожності з 5,3 до 5,16 і фрустрації - 3 5,3 до 5,27; 2) підвищення після тренінгу показників агресивності з 5,2 до 5,38, ригідності - 3 5,3 до 5,33, ситуативної 
тривожності - 3 5,22 до 5,33.

Таблиия 1

Результати описової статистики за методиками Г. Айзенка,

Ч. Спілбергера-Ю. Ханіна та Р. Еліота до і після тренінгу $(n=18)$

\begin{tabular}{|l|c|c|c|c|}
\hline \multirow{2}{*}{\multicolumn{1}{|c|}{ Змінні }} & \multicolumn{2}{c|}{ середнє, } & \multicolumn{2}{c|}{ стандартне відхилення, $\sigma$} \\
\cline { 2 - 5 } & до & після & до & після \\
\hline Тривожність & 5,3056 & 5,1667 & 2,33351 & 2,45549 \\
\hline Фрустрація & 5,3333 & 5,2778 & 2,42536 & 2,58515 \\
\hline Агресивність & 5,1944 & 5,3889 & 2,50962 & 2,45282 \\
\hline Ригідність & 5,3056 & 5,3333 & 2,42620 & 2,43141 \\
\hline Ситуативна тривожність & 5,2222 & 5,3333 & 2,48064 & 2,53795 \\
\hline Якість життя & 5,3056 & 5,3056 & 2,57898 & 2,57898 \\
\hline
\end{tabular}

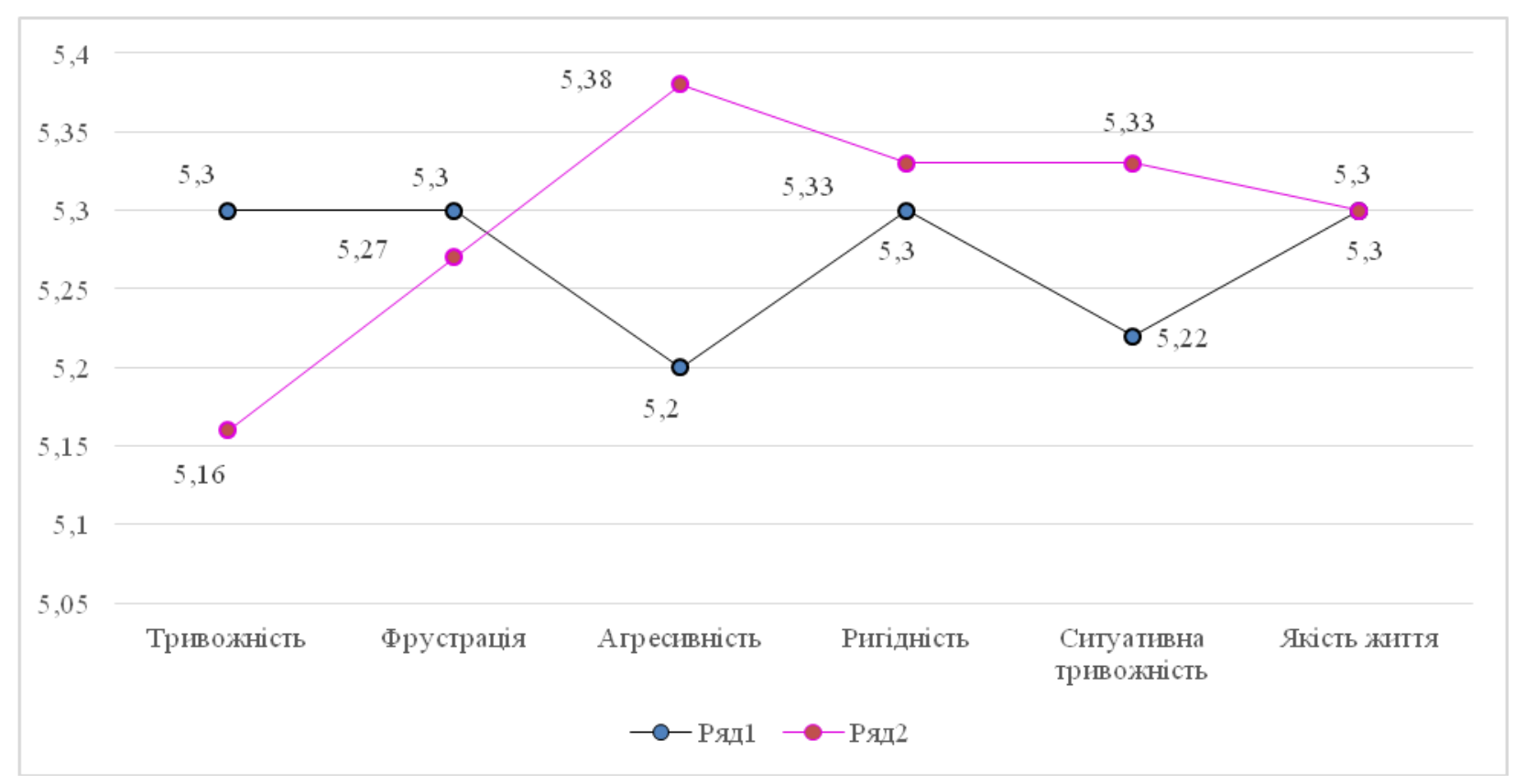

Рис. 1. Середні показники психічних станів досліджуваних за методиками

Г. Айзенка, Ч. Спілбергера-Ю. Ханіна і Р. Еліота (у стенах)

Примітка. Ряд 1 - до тренінгу, ряд 2 - після тренінгу.

3 метою визначення кластерів взаємозв'язків між діагностованими змінними було проведено кореляційний аналіз за Пірсоном. У результаті застосування цієї математичної процедури було встановлено факт посилення міцності і зростання статистичної значущості взаємних зв'язків між показниками психічних станів після проведення поетичного вечоратренінгу порівняно зі зв'язками показників до тренінгу (див. табл. 2 і табл. 3).

Так, якщо до тренінгу зафіксовано значущі зв'язки фрустрації з тривожністю (r=0,454 при $\mathrm{p}=0,05)$, агресивністю $(\mathrm{r}=0,530$ при $\mathrm{p}=0,05)$ і особливо з ригідністю $(\mathrm{r}=0,741$ при $\mathrm{p}=0,01)$; ригідності з тривожністю (r=0,492 при $\mathrm{p}=0,05)$ й агресивністю $(\mathrm{r}=0,412$ при $\mathrm{p}=0,05)$, причому ригідність негативно корелює із загальним показником якості життя $(\mathrm{r}=-0,406$ при $\mathrm{p}=0,05)$; водночас встановлено обернено пропорційну залежність між показником якості життя й особистісною тривожністю ( $\mathrm{r}=-0,740$ при $\mathrm{p}=0,01)$ та ним же i фрустрацією (r=-0,516 при 
$\mathrm{p}=0,05)$ - всього 3 кореляційні плеяди, то після проведеного тренінгу всі відзначені діагностичні показники виявилися взаємно і значуще (на рівні 0,01) пов'язаними, крім показника оцінки якості життя, який послабив свої кореляції, що назагал є позитивним результатом (свідчить про більш оптимістичний погляд особистості на різні аспекти свого існування).

Таблиия 2

Матриця кореляційних зв'язків за методиками Г. Айзенка, Ч. Спілбергера-Ю. Ханіна та Р. Еліота до тренінгу $(n=18)$

\begin{tabular}{|l|c|c|c|c|c|c|}
\hline \multicolumn{1}{|c|}{ Змінні } & $\begin{array}{c}\text { Тривож- } \\
\text { ність }\end{array}$ & Фрустрація & $\begin{array}{c}\text { Агресив- } \\
\text { ність }\end{array}$ & $\begin{array}{c}\text { Ригід- } \\
\text { ність }\end{array}$ & $\begin{array}{c}\text { Ситуативна } \\
\text { тривожність }\end{array}$ & $\begin{array}{c}\text { Якість } \\
\text { життя }\end{array}$ \\
\hline Тривожність & 1 & & & & & \\
\hline Фрустрація & $0,454^{*}$ & 1 & & & & \\
\hline Агресивність & 0,391 & $0,530^{*}$ & 1 & & & \\
\hline Ригідність & $0,492^{*}$ & $0,741^{*}$ & $0,412^{*}$ & 1 & & \\
\hline $\begin{array}{l}\text { Ситуативна } \\
\text { тривожність }\end{array}$ & 0,181 & 0,197 & $-0,390$ & 0,269 & 1 \\
\hline Якість життя & $-0,740^{*}$ & $-0,516^{*}$ & $-0,269$ & $-0,406^{*}$ & $-0,188$ & 1 \\
\hline
\end{tabular}

Таблиия 3

Матриця кореляційних зв'язків за методиками Г. Айзенка, Ч. Спілбергера-Ю. Ханіна та Р. Еліота після тренінгу $(n=18)$

\begin{tabular}{|l|c|c|c|c|c|c|}
\hline \multicolumn{1}{|c|}{ Змінні } & $\begin{array}{c}\text { Тривож- } \\
\text { ність }\end{array}$ & Фрустрація & $\begin{array}{c}\text { Агресив- } \\
\text { ність }\end{array}$ & $\begin{array}{c}\text { Ригід- } \\
\text { ність }\end{array}$ & $\begin{array}{c}\text { Ситуативна } \\
\text { тривожність }\end{array}$ & $\begin{array}{c}\text { Якість } \\
\text { життя }\end{array}$ \\
\hline Тривожність & 1 & & & & & \\
\hline Фрустрація & $0,808^{* *}$ & 1 & & & & \\
\hline Агресивність & $0,623^{* *}$ & $0,668^{* *}$ & 1 & & & \\
\hline Ригідність & $0,655^{* *}$ & $0,794^{* *}$ & $0,717 * *$ & 1 & & \\
\hline $\begin{array}{l}\text { Ситуативна } \\
\text { тривожність }\end{array}$ & 0,080 & 0,084 & 0,143 & 0,041 & 1 & 1 \\
\hline Якість життя & $-0,445^{*}$ & $-0,283$ & 0,082 & $-0,259$ & $-0,322$ & \\
\hline
\end{tabular}

Примітка. ** - кореляція значуща на рівні $\mathrm{p}=0,01 ;$ * $-\mathrm{p}=0,05$.

Порівняння кореляційних плеяд діагностичних показників до та після короткочасної поетичної психотерапії засвідчує зростання внутрішньої інтегрованості осіб, які взяли участь у вечорі поезії, бо, як відомо, внутрішня інтегрованість (цілісність) означає самоприйняття, потужну силу Я, що, своєю чергою, позитивно впливає на життєстійкість особистості, підкреслює її зрілість, а, отже, виступає предиктором духовної трансформації особистості.

Результати проведеного у формі поетичного вечора-тренінгу експериментального дослідження, засадничо націленого на фасилітацію полісуб' єктного і метасуб' єктного рівнів аксіогенезу особистості, свідчать про актуалізацію самого осердя цілісного хронотоп життєздійснення особистості: 1) просторового, діяльнісно-реалізаційного, умовно «горизонтального» й 2) темпорального, духовно-трансцендувального, умовно «вертикального». Про «низ» («горизонталь») і «верх» («вертикаль») людського буття відзначив і А. Мелік-Пашаєв, який спершу задається питанням: «...які найзагальніші, 
глибинні, сталі причини нашого психологічного неблагополуччя і потенційного психічного нездоров’я?», а згодом формулює відповідь: «Образно кажучи, одна з них лежить у «горизонтальному», друга - у «вертикальному» вимірі буття, а сама людина 3 ii усвідомленими і неусвідомленими труднощами і суперечностями перебуває постійно в точці ïх перетину» (Мелик-Пашаев, 2014: 258). Йдеться про соціокультурне самовизначення особистості в контексті тї статусно-рольових взаємодій (адаптивне освоєння топосу персоналізація аксіологічного «низу») - полісуб'єктний рівень персонального аксіогенезу та iii екзистенційно-духовне самовизначення у сенсі взяття на себе відповідальності за сповнення свого покликання - самоактуалізацію у процесі життєтворення (творче опанування хроносом - персоніфікація аксіологічного «верху») - метасуб'єктний рівень персонального аксіогенезу.

Відібрані для поетичного вечора-тренінгу твори дали змогу не лише прицільно фасилітувати відзначені рівні суб'єктно-ціннісного тезаурусу реципієнтів, а й стимулювати іррадіацію душевних порухів і духовних устремлінь в обидві сторони життєвого самовизначення особистості: на «нижчі» рівні: моносуб'єкта - виконавця окремих предметних діяльностей і відносного (психосоматичного) суб'єкта, здатного певною мірою рефлексувати свій життєвий психоемоційний тонус, а також на найвищий, абсолютносуб'єктний (універсальний) рівень «істинного», «вічного», суто «духовного, творчого Я». Ця теза перегукується 3 висновком вищезгаданого А. Мелік-Пашаєва: «...істинна творчість народжується саме на перехресті горизонтальної та вертикальної осей відновлених взаємин людини з самою собою і зі світом» (Мелик-Пашаев, 2014: 261).

Отже, рух-поступ особистості горизонтальним вектором цілісного хронотоп життєздійснення супроводжується реалізацією ії адаптивного потенціалу, а вертикальним вектором - ії справжньою трансформацією (перебудовою, конструюванням, самотворенням). Порівнюючи поняття адаптації та трансформації особистості в процесі подолання життєвих криз, можна знайти певний взаємозв'язок: «Адаптивність - це здатність індивіда або системи модифікувати себе або своє оточення, коли відбуваються несприятливі для них зміни для того, щоб хоча б частково заповнити втрату ефективності» (Акофф \& Эмери, 1974: 129). Адаптація відбувається на трьох функціональних рівнях: фізіологічному, психологічному та соціальному. А.Г. Маклаков оперує поняттям «особистісний адаптаційний потенціал», до якого зараховує нервово-психічну стійкість, самооцінку особистості, соціальну підтримку, конфліктність, комунікабельність, моральність, групову ідентифікацію (Маклаков, 2001).

На думку В.М. Заіки, трансформацію особистості в процесі та внаслідок час подолання життєвих криз можна розглядати як підвищення здатності людини ставати суб'єктом власного життя, беручи відповідальність за результати своїх дій на себе. Відтак, можна простежити зв'язок самозміни із саморозвитком (Заіка, 2006). Учені виокремили такі критерії саморозвитку: опосередкованість, цілеспрямованість, суб'єктність, усвідомленість, дотримуючись думки, що саморозвиток є вищим рівнем саморуху, на якому відбуваються не хаотичні, а цілеспрямовані, усвідомлені зміни, які призводять до якісної трансформації особистості (Максименко, Кузікова \& Зливков, 2017). В.А. Онищенко, слідом за I.I. Чесноковою стверджує, що каталізатором процесу саморозвитку виступає ініціювання, що відбувається в результаті усвідомлення ступеня розходження змісту реального та ідеального Я особистості (Онищенко, 2020: 121). На думку Б.Д. Ельконіна, досвід суб'єктності становить досвід реалізації задуму в способі розв'язання задачі - це досвід ініціативної дії, тобто прийняття на себе труднощів втілення задуму (Эльконин, 2001: 141). 
Отже, сам індивід $\epsilon$ ініціатором самозміни та розвитку, що становить зміст процесу трансформації: «наявне - інше», «реалія - ідея».

Підбиваючи підсумки впровадженню аксіопсихологічного формату короткочасної поетичної психотерапії, зазначимо, що, незважаючи на унікальність способу і форми «інобуття» поетичних творів у художньо-естетичному досвіді реципієнтів, катарсичний ефект і смислотворчий імпульс терапії поезією вражаючий. Залежно від ідейно-тематичної спрямованості й образно-стилістичної специфіки поезії, остання може слугувати експериментальним майданчиком для «ігор у сенс», однак і може, в ладу із заявленою нами методологічною позицією в персонології, втілювати холістичний суб'єктно-ціннісний канон духовного руху-поступу особистості (Карпенко, 2018; Гуляс, 2020).

\section{Висновки}

Аксіопсихологічний формат короткочасної групової поетичної психотерапії передбачає цілеспрямований відбір відповідних текстів 3 урахуванням вікових, соціокультурних, в тому числі гендерно специфічних і професійно-зумовлених особливостей реципієнтів (читачів, слухачів, декламаторів) з метою актуалізації певного (-их) рівня (-ів) людини як інтегрального суб'єкта життєздійснення в діапазоні 1) відносного (умовного), 2) моно-, 3) полі-, 4) метасуб'єктного й 5) абсолютносуб'єктного рівнів 3 відповідними ціннісними орієнтаціями на підтримання здоров'я (1), здобуття істини у пізнанні світу, дотримання справедливості у міжособистісному спілкуванні, отримання користі в професійно-трудовій діяльності (2), доброчинність у взаємодії з іншими людьми (3), естетику культуротворчості (4), прийнятті сущого буття як блага (5).

Предиктором духовної трансформації особистості під впливом сприймання поетичних творів у ближній часовій перспективі виступає динаміка іï психоемоційних станів тривожності, ригідності, агресивності, фрустрованості та сумарного показника якості життя, презентована на відповідних рівнях суб'єктності.

В результаті формувального (психотерапевтичного) експерименту зафіксовано незначну динаміку емпіричних показників діагностованих психічних станів. Найбільші зрушення відбулися в переживанні агресії (+0,18 стени) - рівень полісуб'єкта, що свідчить про наростання конфронтаційного налаштування щодо сумнівних у моральному контексті людських вчинків. За результатами кореляційного аналізу виявлено загальну тенденцію до зростання внутрішньої інтегрованості (гармонізації) психічних станів, що є предиктором зрілої життєвої позиції, сили Я, здатності до самостійного, автентичного смислопокладання особистості. Водночас відбулася позитивна переоцінка реципієнтами поезії якості свого життя, що супроводжувалася більшим самоприйняттям і асертивністю.

Перспективи вивчення поезіотерапії, як засобу духовної трансформації особистості, виглядають надзвичайно обнадійливими. Це, наприклад, психолінгвістичні студії сугестивного і розвивально-корекційного (почасти переконувального) впливу поезії на іiі читача шляхом інтенційного, наративного, дискурсивного аналізів; обгрунтування адресної (діалогічної) спрямованості поетичного твору, що інспірує відповідну естетичну реакцію й емоційно-ціннісне переживання у різних категорій читачів; аналіз образно-метафоричних $\mathrm{i}$ мовно-стилістичних засобів поезії, що зумовлюють іï психотерапевтичний ефект; розроблення програми залучення дітей і молоді до читання і написання поетичних творів як засобів емоційного відреагування внутрішніх і зовнішніх конфліктів особистості, іï духовного зростання і набуття різноманітних культурних компетентностей тощо. 


\section{Література}

1. Акофф, Р., Эмери, Ф.О. (1974). О целеустремленных системах. И.А. Ушаков (Ред.). Москва : Советское радио.

2. Гуляс, I.А. (2020). Аксіопсихологічне проєктування життєвих досягнень особистості. (Монографія). Київ : «Видавництво Людмила».

3. Заіка, В.М. (2006). Особливості трансформації особистості людини в ході вирімення життєвої кризи. Методичні матеріали. Полтава.

4. Карпенко, 3.С. (1998). Аксіопсихологія особистості. Київ : ТОВ «Міжнар. фін. агенція».

5. Карпенко, 3.С. (2010). Наративний простір терапії поезією: суб'єктно-ціннісний підхід. Актуальні проблеми практичної психологї: Збірник наукових праџь, 10, 177-180.

6. Карпова, Н.Л., Лейтес, Н.С. (2014). Библиопсихология и библиотерапия в образовании, воспитании и коррекция. Н.Л. Карпова (Ред.), Библиопсихология. Библиопедагогика. Библиотерапия (с.175-180). Москва : Русская школьная библиотечная ассоциация.

7. Маклаков, А.Г. (2001). Личностный адаптационный потенциал: его мобилизация и прогнозирование в экстремальных условиях. Психологический журнал, 22(1), 16-24.

8. Максименко, С.Д., Кузікова, С.Б., \& Зливков, В.Л. (Ред.). (2017). Особистість як суб'єкт подолання кризових ситуацій: психологічна теорія і практика. (Монографія). Суми : Видво СумДПУ імені А.С. Макаренка.

9. Мелик-Пашаев, А.А. (2014). Искусство и здоровье. Н.Л. Карпова (Ред.), Библиопсихология. Библиопедагогика. Библиотерапия (с. 255-262). Москва : Русская школьная библиотечная ассоциация.

10. Онищенко, В.М. (2020). Трансформація особистості в процесі подолання життєвих криз. Актуальні проблеми психології. Збірник наукових праџь Інституту психологіі імені Г.С. Костюка Національної академії педагогічних наук України., 1(56), 118-124.

11. Рубакин, Н.А. (1977). Психология читателя и книги. Краткое введение в библиологическую психологию. Москва : Книга.

12. Эльконин, Д.Б. (2001). Психология развития. Москва : Издательский Центр Академия.

13. Allen John D., Carter Karen, \& Pearson Mark. (2019). Frangible Emotion Becomes Tangible Expression: Poetry as Therapy with Adolescents. Australian Counselling Research Journal, 13(1), 14-19. Retrieved from https://www.acrjournal.com.au

14. Daboui, P., Janbabai, G., \& Siavash, M. (2018). Hope and mood improvement in women with breast cancer using group poetry therapy: A questionnaire-based before-after study. Journal of Poetry Therapy, 31(3), 165-172. doi: 10.1080/08893675.2018.1467822

15. Hynes, A., \& Hynes-Berry, M. (2011). Biblio/poetry therapy: The interactive process: Ahandbook. Saint Cloud, MI : North Star Press.

16. Leedy, J.J., \& Reiter, S. (2016). Poetry therapy. International Psychotherapy Institute. Retrieved from https://freepsychotherapybooks.org/product/907-Poetry_Therapy.

17. Mazza, N. (2016). Poetry therapy: Theory and practice (2nd ed.). London: Routledge. Retrieved from https://www.taylorfrancis. com/books/9781317606994

18. Muto, Takashi, Hayes Steven, C., \& Jeffcoat, Tami. (2011). The Effectiveness of Acceptance and Commitment Therapy Bibliotherapy for Enhancing the Psychological Health of Japanese College Students Living Abroad. Behavior Therapy, 42(2), 323-335. Retrieved from https://doi.org/10.1016/j.beth.2010.08.009

19. Xerri, D., \& Xerri Agius, S. (2015). Galvanising empathy through poetry. English Journal, 104(4), 71-76.

https://www.danielxerri.com/uploads/4/5/3/0/4530212/xerri_xerri_agius_2015.pdf

\section{References}

1. Akoff, R., \& Emeri, F.O. (1974). O tseleustremlennykh sistemakh [About purposeful systems]. In I.A. Ushakov (Ed.). Moscow : Sovetskoye radio [in Russian].

2. Hulias, I.A. (2020). Aksiopsykholohichne proyektuvannya zhyttyevykh dosyahnen' osobystosti [Axiopsychological design of life achievements of the personality]. Kyiv : Vydavnytstvo «Lyudmyla» [in Ukrainian]. 
3. Zaika, V.M. (2006). Osoblyvosti transformatsiyi osobystosti lyudyny v khodi vyrishennya zhyttyevoyi kryzy. Metodychni materialy [Features of transformation of the person in the course of the decision of a life crisis. Methodical materials]. Poltava [in Ukrainian].

4. Karpenko, Z.S. (1998). Aksiopsykholohiya osobystosti [Axiopsychology of personality]. Kyiv : TOV «Mizhnar. fin. ahentsiya» [in Ukrainian].

5. Karpenko, Z.S. (2010). Naratyvnyy prostir terapiyi poeziyeyu: sub'yektno-tsinnisnyy pidkhid [The narrative space of poetry therapy: a subject-value approach]. Aktual'ni problemy praktychnoyi psykholohiyi: Zbirnyk naukovykh prats' - Actual problems of practical psychology: Collection of scientific works, 10, 177-180 [in Ukrainian].

6. Karpova, N.L., \& Leytes, N.S. (2014). Bibliopsikhologiya i biblioterapiya v obrazovanii, vospitanii i korrektsiya [Bibliopsychology and bibliotherapy in education, upbringing and correction]. In N.L. Karpova (Ed.), Bibliopsikhologiya. Bibliopedagogika. Biblioterapiya Bibliopsychology. Bibliopedagogy. Bibliotherapy (p. 175-180). Moscow : Russkaya shkol'naya bibliotechnaya assotsiatsiya [in Russian].

7. Maklakov, A.G. (2001). Lichnostnyy adaptatsionnyy potentsial: yego mobilizatsiya i prognozirovaniye $\mathrm{v}$ ekstremal'nykh usloviyakh [Personal adaptive potential: its mobilization and forecasting in extreme conditions]. Psikhologicheskiy zhurnal - Psychological journal, 22(1), 16-24 [in Russian].

8. Maksymenko, S.D., Kuzikova, S.B., \& Zlyvkov, V.L. (Eds.). (2017). Osobystist' yak sub'yekt podolannya kryzovykh sytuatsiy: psykholohichna teoriya i praktyka [Personality as a subject of overcoming crisis situations: psychological theory and practice]. Sumy: Vyd-vo SumDPU imeni A.S. Makarenka [in Ukrainian].

9. Melik-Pashayev, A.A. (2014). Iskusstvo i zdorov'ye [Art and health]. In N.L. Karpova (Ed.), Bibliopsikhologiya. Bibliopedagogika. Biblioterapiya - Bibliopsychology. Bibliopedagogy. Bibliotherapy (p. 255-262). Moscow : Russkaya shkol'naya bibliotechnaya assotsiatsiya [in Russian].

10. Onyshchenko, V.M. (2020). Transformatsiya osobystosti v protsesi podolannya zhyttyevykh kryz [Transformation of personality in the process of overcoming life crises]. Aktual'ni problemy psykholohiyi - Actual Problems of Psychology Scientific Papers of the G.S. Kostiuk Institute of Psychology Academy of Pedagogical Sciences of Ukraine, 1(56), 118-124 [in Ukrainian].

11. Rubakin, N.A. (1977). Psikhologiya chitatelya i knigi. Kratkoye vvedeniye v bibliologicheskuyu psikhologiyu ГPsychology of the reader and the book. A brief introduction to bibliological psychology]. Moscow : Kniga [in Russian].

12. El'konin, D.B. (2001). Psikhologiya razvitiya [Developmental psychology]. Moscow : Izdatel'skiy Tsentr Akademiya [in Russian].

13. Allen John, D., Carter, Karen, \& Pearson, Mark. (2019). Frangible Emotion Becomes Tangible Expression: Poetry as Therapy with Adolescents. Australian Counselling Research Journal, 13(1), 14-19. Retrieved from https://www.acrjournal.com.au

14. Daboui, P., Janbabai, G., \& Siavash, M. (2018). Hope and mood improvement in women with breast cancer using group poetry therapy: A questionnaire-based before-after study. Journal of Poetry Therapy, 31(3), 165-172. doi: 10.1080/08893675.2018.1467822

15. Hynes, A., \& Hynes-Berry, M. (2011). Biblio/poetry therapy: The interactive process: Ahandbook. Saint Cloud, MI : North Star Press.

16. Leedy, J.J., \& Reiter, S. (2016). Poetry therapy. International Psychotherapy Institute. Retrieved from https://freepsychotherapybooks.org/product/907-Poetry_Therapy.

17. Mazza, N. (2016). Poetry therapy: Theory and practice (2nd ed.). London: Routledge. Retrieved from https://www.taylorfrancis. com/books/9781317606994

18. Muto, Takashi, Hayes Steven, C., \& Jeffcoat, Tami. (2011). The Effectiveness of Acceptance and Commitment Therapy Bibliotherapy for Enhancing the Psychological Health of Japanese College Students Living Abroad. Behavior Therapy, 42(2), 323-335. Retrieved from https://doi.org/10.1016/j.beth.2010.08.009

19. Xerri, D., \& Xerri Agius, S. (2015). Galvanising empathy through poetry. English Journal, 104(4), 71-76.

https://www.danielxerri.com/uploads/4/5/3/0/4530212/xerri_xerri_agius_2015.pdf 


\title{
POETIC PSYCHOTHERAPY AS A MEANS OF FACILITATION OF PERSONALITY SPIRITUAL TRANSFORMATION Zinoviia Karpenko \\ Doctor of Sciences in Psychology, Professor, Honored Worker of Science and Technology of Ukraine, Professor of the Department of Developmental Psychology \\ Vasyl Stefanyk Precarpathian National University \\ 57, Shevchenko Str., Ivano-Frankivsk, Ukraine, 76025 \\ zinoviia.karpenko@pnu.edu.ua, http://orcid.org/0000-0002-0747-2591
}

\author{
Inesa Hulias \\ Doctor of Sciences in Psychology, Associate Professor, \\ Associate Professor of the Department of Psychology \\ Yuriy Fedkovych Chernivtsi National University \\ 2, Kotsyubynsky Str., Chernivtsi, Ukraine, 58012 \\ i.gulyas@chnu.edu.ua, http://orcid.org/0000-0002-4960-4011
}

\begin{abstract}
Objective. The article considers the axiopsychological substantiation of the use of short-term poetic psychotherapy with the works of moral-ethical and existential-spiritual orientation. The aim of the study was descriptive-phenomenological and experimental-statistical proof of the poetry therapy effectiveness in the short term. The study objectives are to substantiate the feasibility of poetry application as a means of harmonizing current mental states and facilitating the prolonged processes of spiritual transformation of the individual; presentation of axiopsychological (subject-value) format of organization and content of poetry therapy; experimental and statistical verification of the effectiveness of the applied poetic therapy format.

Research methods: Spielberger and Y. Khanin scale of situational anxiety, G. Eisenko's method of diagnostics of mental states, R. Eliot's quality of life questionnaire; descriptive and statistical methods, correlation analysis. Formative experiment was conducted in the form of a poetic eveningtraining. 18 middle-class adults made up the experimental sample.

Results. As a result of the research it has been proved that in the process of poetry therapy there is a harmonization of current mental states and facilitation of personality spiritual transformation in accordance with axiopsychological format of selection and presentation of the author's texts, determined by the principle on the organic, psychosomatic (relative subject); individual, adaptiveactivity (monosubject); interactional, moral and communicative (polysubject); authentic cultural (metasubject); universal, transcendent (absolute subject) levels. The spiritual-transformational potential of poetry is proved to be determined by the intensity and severity of the moral dilemmas embodied in it, and in the near future it is manifested in the dynamics of psycho-emotional states represented at different levels of subjectivity of the recipient of poetry. Conclusions. There is a general tendency to increase the internal integration (harmonization) of mental states, which is a predictor of a mature life position, the strength of the self, the ability to reach an independent, authentic meaning of the individual. At the same time, the recipients of poetry positively re-evaluate the quality of their lives, which is accompanied by greater self-acceptance and assertiveness.

Keywords: axiological psychology, bibliotherapy, spiritual transformation of personality, poetic psychotherapy, facilitation of personality development.
\end{abstract}

